\title{
IMPLEMENTASI PENEGAKAN HUKUM LINGKUNGAN DI DAERAH (STUDI DI KABUPATEN KUNINGAN)*
}

\author{
Suwari Akhmaddhian dan Gios Adhyaksa \\ Fakultas Hukum Universitas Kuningan \\ Email:suwariakhmaddhian@gmail.com
}

\begin{abstract}
Abstrak
Penelitian yang berjudul Implementasi Penegakan Hukum Lingkungan di Daerah (Studi di Kabupaten Kuningan). Lokasi penelitian yaitu dilakukan di Kabupaten Kuningan, Rumusan penelitian yang peneliti dirumuskan adalah Bagimana Implementasi Penegakan Hukum Lingkungan di Kabupaten Kuningan.? Bagaimana Pengaruh Penegakan Hukum Lingkungan Terhadap Perlestarian Lingkungan Hidup di Kabupaten Kuningan? Tujuan penelitian ini adalah untuk mengetahui Implementasi Penegakan Hukum Lingkungan di Kabupaten Kuningan. dan Untuk mengetahui Pengaruh Penegakan Hukum Lingkungan Terhadap Perlestarian Lingkungan Hidup di Kabupaten Kuningan. Penelitian ini dapat dapat berguna antara lain yaitu Penelitian ini secara praktis adalah dapat di gunakan dalam pembuatan kebijakan yang berkaitan dengan lingkungan hidup dan pengaturan dalam penegakahn hukum dalam mendukung pelestarian lingkungan hidup dan konservasi khususnya di Kabupaten Kuningan dan umumnya di Indonesia, Penelitian ini mencoba memberikan gambaran tentang penegakah hukum lingkungan di daerah khususnya di Kabupaten Kuningan, Hasil penelitian ini diharapkan dapat memberikan sumbangan pemikiran bagi pembaharuan khasanah keilmuan terutama yang bekenaan dengan hukum lingkunggan di Indonesia. Metode penelitian yang digunakan oleh peneliti dalam pembahasan penelitian ini adalah metode evaluatif analisis, yaitu suatu metode mengumpulkan dan menyajikan data yang diperoleh untuk menganalisis keadaan yang sebenarnya dan selanjutnya dilakukan analisa rasional berdasarkan acuan yuridis melalui penelitian kepustakaan dan penelitian lapangan. Hasil penelitian menggambarkan bahwa penegakan hukum di daerah khususnya kabupaten kuningan yaitu melalui pembuatan peraturan perundangan yang berkaitan dengan lingkungan hidup, penegakan hukum melalui represif dan persuasif serta peningkatan peran masyarakat sesuai dengan amanat peraturan perundangan.
\end{abstract}

Kata kunci : Implemetasi, Penegakan, Hukum, Lingkungan.

\section{Abstract}

The study, entitled Implementation of Environmental Law Enforcement in the Region (Studies in Kuningan District). The location of research is carried out in the district of Kuningan, formulation research that researchers defined is How to Implementation of Environmental Law Enforcement in Kuningan District.? How to Influence of Environmental Law Enforcement Against Environmental Conservation in Kuningan Regency? The purpose of this study was to determine the Implementation

\footnotetext{
- Artikel ini hasil penelitian hibah Penelitian Dosen Pemula Bagi Dosen Perguruan Tinggi Swasta No.1050/K4/KM/2015, tanggal 31 Maret 2015.
} 
of Environmental Law Enforcement in the district of Kuningan. and To know the effect of Environmental Law Enforcement Against Environmental Conservation in Kuningan District. This research may be useful, among others, the study has practical is that it can be used in policy-making related to environmental and management issues in law enforcement in support of environmental preservation and conservation, especially in the district of Kuningan and generally in Indonesia, this study tries to provide an overview on enforcement of environmental law in the region, especially in the district of Kuningan, expected results of this study can contribute to the renewal of the repertoire of knowledge, especially with respect to environmental laws in Indonesia. The method used by the researchers in the discussion of this study is an evaluative method of analysis, which is a method of collecting and presenting data obtained to analyze the actual situation and then do a rational analysis based on the reference of juridical through library research and field research. The results of the study illustrates that law enforcement in the region, especially kuningan districts namely through the creation of laws and regulations related to the environment, law enforcement through repressive and persuasive as well as increasing the role of the community in accordance with the mandate of legislation.

Keywords: Implementation, Enforcement, Law, Environment..

\section{A. Pendahuluan}

Penegakan hukum merupakan isu yang menarik untuk diteliti karena berkaitan dengan implementasi peraturan perundang-undangan yang berlaku, penegakan hukum lingkungan sangat berkaitan dengan semua aspek kehidupan manusia karena lingkungan merupakan penyangga kehidupan mahluk hidup di bumi ini. Peraturan perundang-undangan yang berkaitan dengan lingkungan hidup yaitu Undang-undang Nomor 32 Tahun 2009 tentang Perlindungan dan Pengelolaan Lingkungan Hidup, Undang-Undang Nomor 05 Tahun 1990 tentang Konservasi Sumberdaya Alam Hayati dan Ekosistemnya, Undang-Undang Nomor 41 Tahun 1999 tentang Kehutanan, Undang-undang Nomor 07 tahun 2004 tentang Sumber Daya Air dan Undang-undang Nomor 11 Tahun 1967 tentang Ketentuan Pokok Pertambangan. Undang-undang Nomor 32 Tahun 2009 tentang Perlindungan dan Pengelolaan Lingkungan Hidup mengatur sanksi kepada pihak yang terbukti melanggar yaitu penegakan hukum dibidang lingkungan hidup dapat diklasifikasikan kedalam 3 (tiga) kategori yaitu : 1). Penegakan hukum Lingkungan dalam kaitannya dengan Hukum Administrasi / Tata Usaha Negara, 2). Penegakan Hukum Lingkungan dalam kaitannya dengan Hukum Perdata, 3). Penegakan Hukum Lingkungan dalam kaitannya dengan Hukum Pidana. 
Kabupaten Kuningan, adalah sebuah kabupaten di Provinsi Jawa Barat, Indonesia. Ibukotanya adalah Kuningan. Letak astronomis kabupaten ini di antara $108^{\circ} 23^{\prime \prime}$ - 108 $47^{\prime \prime}$ Bujur Timur dan 6 $6^{\circ} 45^{\prime \prime}$ $7^{\circ} 13^{\prime \prime}$ Lintang Selatan. Kabupaten ini terletak di bagian timur Jawa Barat, berbatasan dengan Kabupaten Cirebon di utara, Kabupaten Brebes (Jawa Tengah) di timur, Kabupaten Ciamis di selatan, serta Kabupaten Majalengka di barat. Kabupaten Kuningan terdiri atas 32 kecamatan, yang dibagi lagi atas sejumlah 361 desa dan 15 kelurahan. Pusat pemerintahan di Kecamatan Kuningan. Bagian timur wilayah kabupaten ini adalah dataran rendah, sedang di bagian barat berupa pegunungan, dengan puncaknya Gunung Ceremai (3.076 m) yang biasa salah kaprah disebut dengan Gunung Ciremai, gunung ini berada di perbatasan dengan Kabupaten Majalengka. Gunung Ceremai adalah gunung tertinggi di Jawa Barat. Mempunyai luas daerah yaitu 1.178,58 $\mathrm{km}^{2}$ dan Menurut hasil Suseda Jabar tahun 2010, penduduk Kab.Kuningan yang tersebar di 379 desa/kelurahan meliputi 32 kecamatan itu, seluruhnya tercatat 1.873 .528 jiwa.

Permasalahan utama dalam lingkungan hidup yang teridentifikasi ada 5 (lima) antara lain 1 1) kerusakan lahan akibat penggundulan hutan, penebangan liar, alih fungsi lahan untuk perkebunan dan tanaman industri, penambangan minyak, industri dan permukiman; 2) abrasi pinggir sungai akibat laluintas pelayaran kapal-kapal besar dan cepat; 3) pendangkalan sungai oleh tingginya erosi, abrasi dan sedimentasi; 4) gangguan pola aliran air permukaan akibat alih fungsi lahan, keberadaan pelabuhan, dermaga, dan logpond; 5) penurunan kualitas air akibat buangan limbah cair industri, domestik pembuangan air ballast kapal, dan buangan limbah padat domestik. Kabupaten kuningan pada tahun 2006 telah mendeklarasikan sebagai kabupaten konservasi dan pada tahun 2007 terbit Peraturan Daerah Kabupaten Kuningan Nomor 12 Tahun 2007 tentang Konservasi Sumber Daya Air, oleh karena itu untuk mewujudkan kuningan sebagai kabupaten konservasi di perlukan peran dan partisipasi serta dukungan

\footnotetext{
${ }^{1}$ Nana Sudiana dan Hasmana Soewandita, 2007, Pola Konservasi Sumber Daya Air di Daerah Aliran Sungai Siak, Jurnal Alami Vol. 12 Nomor 1, Halaman. 44-51.
} 
semua pihak yang terkait baik pemerintah daerah ataupun masyarakat kabupaten kuningan. Maka dengan adanya penelitian ini diharapkan dapat mengukur dan mengetahui sejauh mana implementasi penegakan hukum lingkungan di kabupaten kuningan dan dalam upaya mendukung kuningan sebagai kabupaten konservasi sesuai dengan harapan dan diharapkan hasil penelitian ini dijadikan landasan dan acuan dari pihak terkait dalam membuat atau memperbaiki kebijakan yang terkait konservasi di kabupaten kuningan. Masalah lingkungan hidup ini dapat ditinjau dari aspek medik, planologis teknologis, teknik lingkungan, ekonomi dan hukum. Hal ini dikemukakan oleh Siti Sundari Rangkuti yaitu segi-segi hukum pengelolaan lingkungan hidup dan konservasi sumber daya alam di Indonesia perlu dikaji secara intensif, karena pengelolaan lingkungan tidak mungkin tanpa pengaturan hukum. Hal ini tidak berarti bahwa ahli hukum dapat menangani masalah lingkungan terlepas dari disiplin ilmu lain yang berkaitan dengan bidang lingkungan hidup ${ }^{2}$.

Adapun yang menjadi pokok permasalahan yang akan menjadi fokus perhatian utama yang akan dibahas dalam penelitian ini dapat di uraikan dalam pertanyaan diantaranya yaitu; Pertama, Bagimana implementasi penegakan hukum lingkungan di Kabupaten Kuningan.? Kedua, Bagaimana pengaruh penegakan hukum lingkungan terhadap perlestarian lingkungan hidup di Kabupaten Kuningan.?

\section{B. Metode Penelitian}

Metode penelitian yang digunakan oleh penyusun dalam pembahasan penelitian ini adalah metode evaluatif analisis, yaitu suatu metode mengumpulkan dan menyajikan data yang diperoleh untuk menganalisis keadaan yang sebenarnya dan selanjutnya dilakukan analisa rasional berdasarkan acuan yuridis melalui penelitian kepustakaan dan penelitian lapangan. Metode penelitian hukum, menurut Soerjono Soekanto adalah " suatu kegiatan ilmiah, yang di dasarkan pada metode, sistematika dan pemikiran tertentu, yang bertujuan

2 Siti Kotijah, 2010, Implementasi Prinsip-prinsip Kehutanan dalam Rangka Konservasi Kehutanan: studi kasus di Jawa Timur, Jurnal Magister Hukum, Vol. 1 Nomor 2, Surabaya : Program Studi Magister Ilmu Hukum, Universitas Wisnuwardhana, Halaman. 354-386 
mempelajari satu atau beberapa gejala hukum tertentu, dengan menganalisanya. ${ }^{3}$ Setelah data terhimpun melalui observasi, angket dan wawancara, maka dilakukan penolahan dan analis data secara kualitatif. Sesuai dengan sifat penelitian ini, yaitu Evaluatif Analisis.

\section{c. Pembahasan}

Suatu penelitian membutuhkan kerangka berpikir untuk menjawab permasalahan-permasalahan yang telah di rumuskan. Kerangka berfikir yang dikenal dalam penelitian hukum terdiri dari atas kerangka teoritis dan kerangka konseptual. 'kerangka teoritis merupakan kerangka dimana masalah di ambil atau di hubungkan'4. Pada umumnya kerangka teoritis disajikan dalam bentuk proposisi atau pernyataan yang salung berkaitan dan bertujuan memberikan gambaran yang sistematis tentang suatu gejala dan selanjutnya dapat membantu kasusu-kasus konkrit yang lebih adil, teori dalam penelitian mempunyai fungsi untuk mengarahkan kepada peneliti apa yang harus dilakukan.

Kerangka konseptual adalah kerangka yang lebih menggambarkan hubungan antara konsep-konsep khusus yang melandasi penelitian. Kerangka konseptual lebih mengedapankan definisi-definisi dari suatu permasalahan dengan kata lain konsep merupakan urianuraian mengenai hubungan-hubungan dalam fakta tersebut ${ }^{5}$.

\section{Pengertian Implementasi}

Pengertian implementasi seperti yang dikemukakan oleh Pranata Wastra dan kawan-kawan adalah Aktivitas atau usaha-usaha yang dilakukan untuk semua rencana dari kebijksanaan yang telah dirumuskan dan ditetapkan, dan dilengkapi segala kebutuhan alatalat yang diperlukan, siapa yang melaksanakan, dimana tempat pelaksanaannya, kapan waktu pelaksanaannya, kapan waktu mulai dan berakhirnya dan bagaimana cara yang harus dilaksanakan.

\footnotetext{
3 Soerjono Soekanto, Pengantar Penelitian Hukum.cet.2007, Jakarta : UI Press, 1984 , hlm.5

${ }^{4}$ Soerjono Soekanto, Ringkasan Metode Penelitian Hukum Empiris, Jakarta:Ind-Hill 1990, hlm 110.

${ }^{5}$ Soerjono Soekanto, Pengantar Penelitian Hukum.cet.2007, Jakarta : UI Press, 1984, hlm.132.
} 
Sementara Budi Winarno, yang mengatakan bahwa implementasi kebijakan dibatasi sebagai menjangkau tindakantindakan yang dilakukan oleh individu-individu pemerintah dan individu-individu swasta (kelompok-kelompok) yang diarahkan untuk mencapai tujuan-tujuan yang telah ditetapkan dalam keputusan-keputusan kebijaksanaan sebelumnya.

Adapun makna implementasi menurut Daniel A. Mazmanian dan Paul Sabatier sebagaiamana dikutip dalam buku Solihin Abdul Wahab, mengatakan bahwa, yaitu, Implementasi adalah memahami apa yang senyatanya terjadi sesudah suatu program dinyatakan berlaku atau dirumuskan merupakan fokus perhatian implementasi kebijaksanaan yakni kejadian-kejadian dan kegiatan-kegiatan yang timbul sesudah disahkannya pedoman-pedoman kebijaksanaan Negara yang mencakup baik usaha-usaha untuk mengadministrasikannya maupun untuk menimbulkan akibat/dampak nyata pada masyarakat atau kejadian-kejadian. Dari pandangan kedua ahli diatas dapat dikatakan bahwa suatu proses implementasi kebijaksanaan itu sesungguhnya tidak hanya menyangkut perilaku badan-badan adminstratif yang bertanggung jawab untuk melaksanakan suatu program yang telah ditetapkan serta menimbulkan ketaatan pada diri kelompok sasaran, melainkan pula menyangkut jaringan kekuatan-kekuatan poltik, ekonomi, dan social yang secara langsung maupun tidak langsung dapat mempengaruhi segala pihak yang terlibat, sekalipun dalam hal ini dampak yang diharapkan ataupun yang tidak diharapakan.

Van Meter dan Van Horn dalam Budi Winarno, membatasi implementasi kebijakan sebagai tindakan-tindakan yang dilakukan individu-individu (kelompok-kelompok) pemerintah maupun swasta yang diarahkan untuk mencapai tujuan-tujuan yang telah ditetapkan dalam keputusan-keputusan sebelumnya.

Micahel Howlet dan M. Ramesh $(1995 ; 11)$ dalam buku Subarsono, bahwa implementasi kebijakan adalah proses untuk melakukan kebijakan supaya mencapai hasil. dari defenisi diatas dapat diketahui bahwa implementasi kebijakan terdiri dari tujuan 
atau sasaran kebijakan, aktivitas, atau kegiatan pencapaian tujuan, dari hasil kegiatan. Sehingga dapat disimpulkan bahwa implementasi merupakan suatu proses yang dinamis, dimana pelaksana kebijakan melakukan suatu aktivitas atau kegiatan, sehingga pada akhirnya akan mendapatkan suatu hasil yang sesuai dengan tujuan atau sasaran kebijakan itu sendiri. Keberhasilan suatu implementasi kebijakan dapat diukur atau dilihat dari proses dan pencapaian tujuan hasil akhir (output), yaitu : tercapai atau tidaknya tujuan-tujuan yang ingin diraih. Van Meter dan Van Horn dalam Budi Winarno, membatasi implementasi kebijakan sebagai tindakan-tindakan yang dilakukan individu-individu (kelompokkelompok) pemerintah maupun swasta yang diarahkan untuk mencapai tujuan-tujuan yang telah ditetapkan dalam keputusankeputusan sebelumnya.

\section{Pengertian Penegakan Hukum}

Definisi penegakan hukum menurut Kamus Besar Bahasa Indonesia (KBBI) memiliki arti yang sangat luas meliputi segi preventif dan represif, cocok dengan kondisi Indonesia yang unsur pemerintahnya turut aktif dalam meningkatkan kesadaran hukum masyarakat. Penegakan hukum menurut Satjipto Rahardjo, merupakan suatu proses untuk mewujudkan keinginan-keinginan hukum menjadi kenyataan. ${ }^{6}$ Keinginan-keinginan hukum yang dimaksudkan di sini yaitu yang merupakan pikiran-pikiran badan pembentuk undang-undang yang dirumuskan dalam peraturanperaturan hukum itu. Perumusan pikiran pembuat hukum yang dituangkan dalam peraturan hukum, turut menentukan bagaimana penegakan hukum itu dijalankan. Dengan demikian pada gilirannya, proses penegakan hukum itu memuncak pada pelaksanaannya oleh para pejabat penegak hukum itu sendiri. Dari keadaan ini, dengan nada ekstrim dapat dikatakan bahwa keberhasilan ataupun kegagalan para penegak hukum dalam melaksanakan tugasnya sebetulnya sudah dimulai sejak peraturan hukum yang harus

\footnotetext{
${ }^{6}$ Satjipto Rahardjo, 1983, Masalah Penegakan Hukum, Bandung: Sinar Baru, hal. 24
} 
dijalankan itu dibuat. ${ }^{7}$ Proses penegakan hukum, dalam pandangan Soerjono Soekanto, dipengaruhi oleh 5 (lima) faktor ${ }^{8}$. Pertama, faktor hukum atau peraturan perundangundangan. Kedua, faktor aparat penegak hukumnya, yakni pihak-pihak yang terlibat dalam peroses pembuatan dan penerapan hukumnya, yang berkaitan dengan masalah mentalitas. Ketiga, faktor sarana atau fasilitas yang mendukung proses penegakan hukum. Keempat, faktor masyara-kat, yakni lingkungan social di mana hukum tersebut berlaku atau diterapkan; berhubungan dengan kesadaran dan kepatuhan hukum yang merefleksi dalam perilaku masyarakat. Kelima, faktor kebudayaan, yakni hasil karya, cipta dan rasa yang didasarkan pada karsa manusia di dalam pergaulan hidup.

Sementara itu Satjipto Rahardjo, membedakan berbagai unsur yang berpengaruh dalam proses penegakan hukum berdasarkan derajat kedekatannya pada proses, yakni yang agak jauh dan yang agak dekat. Berdasarkan criteria kedekatan tersebut, maka Satjipto Rahardjo membedakan 3 (tiga) unsur utama yang terlibat dalam proses penegakan hukum ${ }^{9}$. Pertama, unsur pembuatan undang-undang cq. lembaga legislatif. Kedua, unsur penegakan hukum cq. polisi, jaksa dan hakim. Dan ketiga, unsur lingkungan yang meliputi pribadi warga negara dan sosial. Pada sisi lain, Jerome Frank, juga berbicara tentang berbagai faktor yang turut terlibat dalam proses penegakan hukum. Beberapa faktor ini selain faktor kaidah-kaidah hukumnya, juga meliputi prasangka politik, ekonomi, moral serta simpati dan antipati pribadi ${ }^{10}$. Sementara itu, Lawrence M. Friedman melihat bahwa keberhasilan penegakan hukum selalu menyaratkan berfungsinya semua komponen system hukum. Sistem hukum dalam pandangan Friedman terdiri

\footnotetext{
${ }^{7}$ Ibid, hal. 25

${ }^{8}$ Soerjono Soekanto, 1983, Penegakan Hukum, Jakarta: BPHN \& Binacipta, hal. 15

9 Satjipto Rahardjo,1983, Masalah Penegakan Hukum ,Bandung: Sinar Baru, hal. 23,24 .

10 Lili Rasjidi, 1991, Filsafat Hukum Apakah Hukum Itu?, Bandung: Remaja Rosdakarya, hal. 51.
} 
dari tiga komponen ${ }^{11}$, yakni komponen struktur hukum (legal structure), komponen substansi hukum (legal substance) dan komponen budaya hukum (legal culture). Struktur hukum (legal structure) merupakan batang tubuh, kerangka, bentuk abadi dari suatu sistem. Substansi hukum (legal substance) aturan-aturan dan norma-norma actual yang dipergunakan oleh lembaga-lembaga, kenyataan, bentuk perilaku dari para pelaku yang diamati di dalam sistem. Adapun kultur atau budaya hukum (legal culture) merupakan gagasan-gagasan, sikap-sikap, keyakinan-keyakinan, harapanharapan dan pendapat tentang hukum. Dalam perkembangan-nya, Friedman menambahkan pula komponen yang keempat, yang disebutnya komponen dampak hukum (legal impact). Dengan komponen dampak hukum ini yang dimaksudkan adalah dampak dari suatu keputusan hukum yang menjadi objek kajian peneliti. Berkaitan dengan budaya hukum (legal culture) ini, menurut Roger Cotterrell, konsep budaya hukum itu menjelaskan keanekaragaman ide tentang hukum yang ada dalam berbagai masyarakat dan posisinya dalam tatanan sosial. Ideide ini menjelaskan tentang praktik-praktik hukum, sikap warga Negara terhadap hukum dan kemauan dan ketidakmauannya untuk mengajukan perkara, dan signifikansi hukum yang relatif, dalam menjelaskan pemikiran dan perilaku yang lebih luas di luar praktik dan bentuk diskursus khusus yang terkait dengan lembaga hukum. Dengan demikian, variasi budaya hukum mungkin mampu menjelaskan banyak tentang perbedaan-perbedaan cara di mana lembaga hukum yang nampak sama dapat berfungsi pada masyarakat yang berbeda ${ }^{12}$. Substansi hukum dalam wujudnya sebagai peraturan perundangundangan, telah diterima sebagai instrumen resmi yang memeproleh aspirasi untuk dikembangkan, yang diorientasikan secara pragmatis untuk menghadapi masalah-masalah sosial yang kontemporer. Hukum dengan karakter yang demikian itu lebih

\footnotetext{
${ }^{11}$ Lawrence M. Friedman, 1984, American Law: An invalueable guide to the many faces of the law, and how it affects our daily lives, New York: W.W. Norton \& Company, hal 16.

12 Mochtar Kusumaatmadja, 1986, Fungsi dan Perkem-bangan Hukum dalam Pembangunan Nasional, Bandung: Binacipta, hal. 11.
} 
dikenal dengan konsep hukum law as a tool of social engineering dari Roscoe Pound, atau yang di dalam terminologi Mochtar Kusumaatmadja disebutkan sebagai hukum yang berfungsi seba-gai sarana untuk membantu perubahan masyarakat. ${ }^{13}$ Karakter keberpihakan hukum yang responsif ini, sering disebutkan sebagai hukum yang emansipatif. Hukum yang emansipatif mengindikasikan sifat demokratis dan egaliter, yakni hukum yang memberikan perhatian pada upaya memberikan perlindungan hak-hak asasi manusia dan peluang yang lebih besar kepada warga masyarakat yang lemah secara sosial, ekonomi dan politis untuk dapat mengambil peran partisipatif dalam semua bidang kehidupan bermasyarakat, berbangsa dan bernegara. Dikatakan bahwa hukum yang responsif terdapat di dalam masyarakat yang menjunjung tinggi semangat demokrasi. Hukum responsif menampakkan ciri bahwa hukum ada bukan demi hukum itu sendiri, bukan demi kepentingan praktisi hukum, juga bukan untuk membuat pemerintah senang, melainkan hukum ada demi kepentingan rakyat di dalam masyarakat. ${ }^{14}$

Berkaitan dengan karakter dasar hukum positif ini, Sunaryati Hartono melihat bahwa Undang-Undang Dasar 1945 disusun dengan lebih berpegang pada konsep hukum sebagai sarana rekayasa sosial ini ${ }^{15}$. Karakter hukum positif dalam wujudnya sebagai peraturan peraturan perundang-undangan, di samping ditentukan oleh suasana atau konfigurasi politik momentum pembuatannya, juga berkaitan erat dengan komitmen moral serta profesional dari para anggota legislatif itu sendiri. Oleh karena semangat hokum (spirit of law) yang dibangun berkaitan erat dengan visi pembentuk undangundang, maka dalam konteks membangun hukum yang demokratis, tinjauan tentang peran pembentuk undang-undang penting dilakukan. Dikemukakan oleh Gardiner bahwa pembentuk undang-undang tidak semata-mata berkekewajiban to adapt the law to this changed

\footnotetext{
${ }^{13}$ Ibid, hal. 18.

${ }^{14}$ Max Weber dalam A.A.G. Peters dan Koesriani Siswosoebroto, 1988, Hukum dan Perkembangan Sosial (Buku I), Jakarta: Sinar Harapan, hal. 483

15 C.F.G. Sunaryati Hartono, 1991, Politik Hukum Menuju Satu Sistem Hukum Nasional, Bandung: Alumni, hal. 53.
} 
society, melainkan juga memiliki kesempatan untuk memberikan sumbangan terhadap pembentukan perubahan masyarakat itu sendiri. Pembentuk undang-undang, dengan demikian, tidak lagi semata-mata mengikuti perubahan masyarakat, akan tetapi justru mendahului perubahan masyarakat itu. Dalam kaitan ini Roeslan Saleh menegaskan bahwa masyarakat yang adil dan makmur serta modern yang merupakan tujuan pembangunan bangsa, justru sesungguhnya merupakan kreasi tidak langsung dari pembentuk undang-undang. ${ }^{16}$

Istilah penegakan hukum dalam Bahasa Indonesia membawa kita kepada pemikiran bahwa penegakan hukum selalu dengan paksaan sehingga ada yang berpendapat bahwa penegakan hukum hanya bersangkutan dengan hukum pidana saja. Penegakan hukum memiliki arti yang sangat luas meliputi segi preventif dan represif, cocok dengan kondisi Indonesia yang unsur pemerintahnya turut aktif dalam meningkatkan kesadaran hukum masyarakat. Secara konsepsional, maka inti dan arti penegakan hukum terletak pada kegiatan menyerasikan hubungan nilai-nilai yang terjabarkan di dalam kaidah-kaidah yang mantap dan sikap tindak sebagai rangkaian penjabaran nilai tahap akhir untuk menciptakan, memelihara dan mempertahankan kedamaian pergaulan hidup. Penegakan hukum lingkungan merupakan penegakan hukum yang cukup rumit karena hukum lingkungan menempati titik silang antara antara berbagai bidang hukum klasik.

Penegakan hukum lingkungan merupakan mata rantai terakhir dalam siklus pengaturan perencanaan kebijakan tentang lingkungan yang urutannya sebagai berikut: 1.). Perundang-undangan, 2). Penentuan standar, 3). Pemberian izin, 4). Penerapan, 5). Penegakan hukum. Menurut Mertokusumo, kalau dalam penegakan hukum, yang diperhatikan hanya kepastian hukum, maka unsur-unsur lainnya dikorbankan. Demikian pula kalau yang diperhatikan hanyalah kemanfaatan, maka kepastian hukum dan keadilan dikorbankan. Oleh

\footnotetext{
${ }^{16}$ Roeslan Saleh, 1979, Penjabaran Pancasila dan UUD 1945 Dalam Perundangundangan, Jakarta: Bina Aksara, hal. 12
} 
karena itu dalam penegakan hukum lingkungan ketiga unsur tersebut yaitu kepastian, kemanfaatan, dan keadilan harus dikompromikan. Artinya ketiganya harus mendapat perhatian secara proposional seimbang dalam penanganannya, meskipun di dalam praktek tidak selalu mudah melakukannya. Berbeda halnya dengan M. Daud Silalahi yang menyebutkan bahwa penegakan hukum lingkungan mencakup penaatan dan penindakan yang meliputi hukum administrasi negara, bidang hukum perdata dan bidang hukum pidana. Undang-Undang No.32 Tahun 2009 tentang Perlindungan dan Pengelolaan Lingkungan Hidup menyediakan tiga macam penegakan hukum lingkungan yaitu penegakan hukum administrasi, perdata dan pidana. Diantara ke tiga bentuk penegakan hukum yang tersedia, penegakan hukum administrasi dianggap sebagai upaya penegakan hukum terpenting. Hal ini karena penegakan hukum administrasi lebih ditunjukan kepada upaya mencegah terjadinya pencemaran dan perusakan lingkungan. Di samping itu, penegakan hukum administrasi juga bertujuan untuk menghukum pelaku pencemaran dan perusakan lingkungan. Penegakan hukum adalah proses dilakukannya upaya tegaknya atau berfungsinya norma-norma hukum secara nyata sebagai pedoman perilaku dalam hubungan-hubungan dalam kehidupan bermasyarakat dan bernegara. Ditinjau dari subyeknya, penegakan hukum dapat dilakukan oleh subyak yang luas dan dapat pula diartikan sebagai upaya penegakan hukum itu melibatkan semua subyek hukum dalam setiap hubungan hukum.menurut subyeknya penegakan hukum dapat diartikan sebagai upaya aparatur penegak hukum tertentu untuk menjamin dan memastikan tegaknya hukum itu dan aparatur penegak hukum itu dapat menggunakan daya paksa untuk dalam proses penegakan hukum. ${ }^{17}$

\section{Pengertian Lingkungan}

Definisi Lingkungan menurut Kamus Besar Bahasa Indonesia (KKBI) berarti, (1) daerah (kawasan dsb) yg termasuk di dalamnya;

\footnotetext{
${ }^{17}$ Kartono, 2009, Penegakan Hukum Lingkungan Administratif Dalam Undang-Undang Perlindungan dan Pengelolaan Lingkungan Hidup, Jurnal Dinamika Hukum, Vol.09 No. 3, Purwekerto: FH UNSOED, halaman 247-257.
} 
(2) bagian wilayah dl kelurahan yg merupakan lingkungan kerja pelaksanaan pemerintahan desa; (3) golongan; kalangan: ia berasal $\mathrm{dr} \sim$ bangsawan; (4) semua yg mempengaruhi pertumbuhan manusia atau hewan: kita harus mencegah pencemaran sedangkan lingkungan hidup mempunyai arti (1) kesatuan ruang dng semua benda, daya, keadaan, dan makhluk hidup, termasuk manusia dan perilakunya yg mempengaruhi perikehidupan dan kesejahteraan manusia serta makhluk hidup lainnya; (2) lingkungan di luar suatu organisme yg terdiri atas organisme hidup, spt tumbuhan, hewan, dan manusia. Pengertian lingkungan hidup adalah semua benda, daya dan kondisi yang terdapat dalam suatu tempat atau ruang tempat manusia atau makhluk hidup berada dan dapat mempengaruhi hidupnya. Istilah lingkungan hidup, dalam bahasa Inggris disebut dengan environment, dalam bahasa Belanda disebut dengan millieu atau dalam bahasa Perancis disebut dengan l'environment. Dalam kamus lingkungan hidup yang disusun Michael Allaby, lingkungan hidup itu diartikan sebagai: the physical, chemical and biotic condition surrounding and organism. S.J. McNaughton dan Larry L. Wolf mengartikannya dengan semua faktor eksternal yang bersifat biologis dan fisika yang langsung mempengaruhi kehidupan, pertumbuhan, perkembangan dan reproduksi organism Prof. Dr. Ir. Otto Soemarwoto, seorang ahli ilmu lingkungan (ekologi) terkemuka mendefinisikannya sebagai berikut: Lingkungan adalah jumlah semua benda dan kondisi yang ada dalam ruang yang kita tempati yang mempengaruhi kehidupan kita. Prof. Dr St. Munadjat Danusaputro, $\mathrm{SH}$, ahli hukum lingkungan terkemuka dan Guru Besar Hukum Lingkungan Universitas Padjadjaran mengartikan lingkungan hidup sebagai semua benda dan kondisi, termasuk di dalamnya manusia dan tingkah perhuatannya, yang terdapat dalam ruang tempat manusia berada dan mempengaruhi hidup serta kesejahteraan manusia dan jasad hidup lainnya.

\section{Pembahasan}




\section{Implementasi Penegakan Hukum Lingkungan di Kabupaten Kuningan.}

Kabupaten kuningan pada tahun 2006 telah mendeklarasikan sebagai kabupaten konservasi dan pada tahun 2007 terbit Peraturan Daerah Kabupaten Kuningan Nomor 12 Tahun 2007 tentang Konservasi Sumber Daya Air, oleh karena itu untuk mewujudkan kuningan sebagai kabupaten konservasi di perlukan penegakan hukum dan partisipasi serta dukungan semua pihak yang terkait baik pemerintah daerah ataupun masyarakat kabupaten kuningan. Maka dengan adanya penelitian ini diharapkan dapat mengukur dan mengetahui sejauh mana peran pemerintah daerah kabupaten kuningan dalam mendukung kuningan sebagai kabupaten konservasi sesuai dengan harapan dan diharapkan hasil penelitian ini dijadikan landasan dan acuan dari pihak terkait dalam membuat atau memperbaiki kebijakan yang terkait konservasi di kabupaten kuningan. Mengatasi tantangan konservasi sumberdaya air di perlukan komitmen politik yang kuat dari pemerintah untuk melakukan kebijakan pengelolaan sumberdauya air yang holistik termasuk mengantisipasi tantangan konservasi pada saat pengusahaan air bersih yang dilakukan oleh koporasi privat ${ }^{18}$. Satjipto Rahardjo, membedakan berbagai unsur yang berpengaruh dalam proses penegakan hukum berdasarkan derajat kedekatannya pada proses, yakni yang agak jauh dan yang agak dekat. Berdasarkan criteria kedekatan tersebut, maka Satjipto Rahardjo membedakan 3 (tiga) unsur utama yang terlibat dalam proses penegakan hukum ${ }^{19}$. Pertama, unsur pembuatan undang-undang $\mathrm{cq}$. lembaga legislatif. Kedua, unsur penegakan hukum cq. polisi, jaksa dan hakim dan ketiga, unsur lingkungan yang meliputi pribadi warga negara dan sosial.

\footnotetext{
${ }^{18}$ Budi Widianarko, Privatisasi dan Tantangan Konservasi Sumber Daya Air, Jurnal Renai edisi Air : Hak Asasi Versus Komodifikasi, Pustaka Percik, 2005, Halaman. 49 57

19 Satjipto Rahardjo,1983, Masalah Penegakan Hukum ,Bandung: Sinar Baru, hal. 23,24 .
} 
Berdasarkan uraian diatas untuk mencapai tujuan konservasi di kabupaten kuningan maka pemerintah daerah kabupaten kuningan melakukan upaya-upaya dalam hal kebijakan yaitu dengan membuat peraturan-peraturan yang berkaitan dan yang mendukung konservasi sumber daya air. Selain membuat kebijakan-kebijakan yang berkaitan dengan lingkungan kabupaten kuningan juga meningkatkan status Hutan Lindung Gunung Cermai menjadi Taman Nasional Gunung Cermai, membuat Hutan Kota dan membuat Waduk atau Embung di berbagai wilayah, adapun rinciannya sebagai berikut : 1). Taman Nasional Gunung Cermai (TNGC) seluas 8.935 ha, 2). Kebun Raya Kuningan di Kecamatan Pasawahan seluas 154,90 ha, 3). Hutan Kota tersebar di 17 Lokasi (12 Kecamatan) seluas 71,5 ha 4). Taman Wisata Alam Linggarjati seluas 15 ha. 5). Waduk/Situ/Embung di 114 Lokasi

Penegakan hukum yang bersifat represif dilakukan oleh penegak hukum yaitu polisi di kepolisian, jaksa di kejaksaan dan hakim di pengadilan sebagaimana menurur pendapat Sapjito Raharjo di kabupaten kuningan dilakukan yaitu terhadap kasus penebangan pohon yang dilakukan oleh warga kecamatan cibingbin dan Penutupan galian $C$ di kecamatan cidahu yang melanggar peraturan perundangan dan pengentian proyek-proyek yang tidak memiliki perizinan sesuai dengan peraturan perundangan yang berlkau. Penegakan hukum yang ketiga menurut Sapjito Raharjo adalah unsur lingkungan seperti pribadi masyarakat, penegakan hukum ini dilakukan yaitu melalui pemberdayaan masyaraka dengan turut serta berpartisipasi dalam pengelolaan dan perlindungan lingkungan hidup melalui program-program yang bersifat persuasive antara lain ${ }^{20}$ :

a. Program Seruling (siswa peduli lingkungan), Seruling adalah program yang mengikutsertakan siswa dalam melakukan konservasi lingkungan dengan cara menanam pohon di lingkungan sekolah sehingga lingkungan menjadi asri dan nyaman dalam

20 Suwari Akhmaddhian, Peran Pemerintah Daerah dalam Mewujudkan Hutan Konservasi Berdasarkan Undang-undang Nomor 41 tahun 1999 tentang Kehutanan (Studi di Kabupaten Kuningan), Jurnal Dinamika Hukum, Vol.13 No. 3 September 2013, Purwekerto: FH UNSOED, halaman 455-456 
kegiatan belajar mengajar adapun program ini diharuskan siswa baru membawa bibit pohon sebagai bentuk partisipasi siswa dalam mewujudkan kuningan sebagai kabupaten konservasi, program ini sudah dan terus berjalan dan terus berkembang meluas tidak saja kalangan siswa baru di kabupaten kuningan tapi sudah menularkan ke kalangan perguruan tinggi yaitu dengan adanya kegiatan penanaman pohon olah para mahasiswa baru di lingkungan perguruan tinggi di kabupaten kuningan. Selain kegiatan penanaman pohon konservasi juga masuk kedalam kurikulum pendidikan yang ada di kabupaten kuningan. Program seruling dilakukan oleh beberapa sekolah yaitu seperti SMKN 1 Kuningan dengan melakukan penenanaman pohon di Kecamatan Cigugur dan SMA ITUS melakukan penanaman di lereng gunung cermai.

b. Program Apel (aparat peduli lingkungan), Apel adalah program yang menyentuh kalangan aparatur pemerintah di kabupaten kuningan yaitu dengan kegiatan penanaman pohon yang berkaitan dengan kenaikan pangkat serta hari bumi dan hari besar lainnya, dalam program ini setiap pegawai atau aparatur di pemerintah daerah yang naik pangkat harus menyediakan dan menanam pohon di wilayah yang sudah di tentukan tentunya ini merupakan kegiatan yang sangat baik dalam mendukung program pemerintah daerah.

c. Program Pepeling (pengantin peduli lingkungan), Pepeling adalah program kerjasama dengan Kementrian Agama khususnya adalah Kantor Urusan Agama di setiap kecamatan dalam program ini setiap calon pengantin yang akan menikah diharuskan memberikan 10 bibit pohon yang diserahkan dan akan ditanam oleh dinas teknis yang membidangi lingkungan hidup.

d. Program Car Free Day adalah program yang berkaitan dengan berkegiatan yang tidak menggunakan kendaraan yang bermesin, kegiatan ini dilakukan pada hari libur didalam kota kuningan sehingga terjadi penghentian sementara polusi yang disebabkan oleh asap kendaraan bermotor selain itu juga program car free 
day menjadi ajang silaturahmi antar warga di kabupaten kuningan dan juga menjadi sarana para pedagang atau ukm untuk menjajakan barang atau produk yang menjadi usahanya.

\section{Pengaruh Penegakan Hukum Lingkungan Terhadap Perlestarian Lingkungan Hidup di Kabupaten Kuningan.}

Penegakan hukum lingkungan terhadap pelestarian lingkungan hidup di kabupaten kuningan mempunyai pengaruh yang baik terhadap fungsi pelestarian lingkungan hidup yaitu adanya reklamsi terhadap bekas galian-galian tambang menjadi taman contohnya yaitu hutan kota mayasih yang terletak di kecamatan cigugur kuningan seluas 3 hektar yang merupakan lahan bekas galian kemudian direklamsi menjadi hutan kota dan tujuan pariwisata berbasis lingkungan hidup. Pencegahan keruksakan lingkungan juga di lakukan oleh Pemerintah Kabupaten Kuningan melalui Badan Pelayanan Perizinan Terpadu (BPPT) Kuningan didampingi Dinas Tata Ruang dan Cipta Karya (DTRCK), BPLHD serta Satuan Polisi Pamong Praja (Satpol PP) melakukan sidak ke sejumlah proyek,. Sejumlah proyek terpaksa dihentikan karena proses perijinan belum ditempuh.

Penghentian sementara proyek tersebut. sebab, beberapa proyek seperti galian tanah merah di Oleced, pengangkutan bahan tanah merah yang diperuntukan dibangun lahan parkir pabrik, serta bangunan untuk pengolahan limbah plastik milik pabrik air mineral merk San Aqua di Bandorasa belum mengantongi izin. Pihaknya menjelaskan, bahwa tindakan tersebut berdasarkan informasi warga yang mengeluhkan aktifitas proyek baik di daerah Oleced maupun yang ada di Bandorasa. Namun, tindakan tegas yang ditempuh juga berdasarkan aturan sesuai hukum yang berlaku. Dan Pagundan Regency namun tidak melakukan penutupan. Hanya saja, pihak pengembang harus menyesuaikan dengan sepadan yang ada 
dengan memundurkan bangunan sejauh 3,5 meter dari bahu jalan. Untuk bangunan di Bandorasa yang bakal difungsikan pengolahan limbah plastik, pihak pabrik diwajibkan untuk memundurkan bangunan sejauh 5 meter dari bahu jalan. Pembangunan di hentikan dahulu proyek-proyek itu sebelum izin ditempuh. Apalagi, mereka juga sudah siap untuk mengurus perizinan agar segera dikeluarkan.

\section{E. Penutup}

\section{Simpulan}

a. Implementasi penegakan hukum lingkungan di Kabupaten Kuningan menurut Satjipto Rahardjo, membedakan berbagai unsur yang berpengaruh dalam proses penegakan hukum berdasarkan derajat kedekatannya pada proses, yakni yang agak jauh dan yang agak dekat. Berdasarkan criteria kedekatan tersebut, maka Satjipto Rahardjo membedakan 3 (tiga) unsur utama yang terlibat dalam proses penegakan hukum ${ }^{21}$. Pertama, unsur pembuatan undang-undang cq. lembaga legislatif. Kedua, unsur penegakan hukum cq. polisi, jaksa dan hakim dan ketiga, unsur lingkungan yang meliputi pribadi warga negara dan social. Di kabupaten kuningan penegakan hukum yang pertama yaitu dibuatnya peraturan perundang-undangan yang terkait pelestarian lingkungan hidup. Unsur kedua yaitu unsur penegakan hukum cq. polisi, jaksa dan hakim dalam hal ini adalah aparatur pemerintah daerah yaitu BPLHD Kabupaten Kuningan bekerjasama dengan penegak hukum. Unsur yang ketiga yaitu unsur lingkungan yang meliputi pribadi warga negara dan social di masyarakat kabupaten kuningan sendiri ada model-model partisipasi dan peran masyrakat seperti Seruling (siswa peduli lingkungan), Apel (aparat peduli lingkungan) dan Pepeling (pengantin peduli lingkungan).

${ }^{21}$ Satjipto Rahardjo,1983, Masalah Penegakan Hukum ,Bandung: Sinar Baru, hal. 23,24 . 
b. Pengaruh penegakan hukum lingkungan terhadap perlestarian lingkungan hidup di Kabupaten Kuningan yaitu para pihak yang melakukan tindakan-tindakan yang tidak sesuai dengan peraturan perundang-undangan di tindak tegas sesuai dengan peraturan yang ada mulai dari peringatan sampai dengan penghentian kegiatan.

\section{Saran}

a. Implementasi penegakan hukum lingkungan di Kabupaten Kuningan merupakan hal yang harus dilaksanakan terus-menerus dan berkesinambungan mulai dari yang bersifat persuasif sampai dengan represif. Bersifat persuasif atau preventif dilakukan melalui cara sosialisai dan penyuluhan hukum terhadap peraturan perundang-undangan yang ada baik peratuarn yang bersifat pusat seperti Undang-undang, Peraturan pemerintah, Peraturan presiden, dan peraturan lainnya juga peraturan daerah. Penegakan hukum yang bersifat represif tentu diperlukan ketika para pihak sudah tidak mengindahkan peringatan-peringatan yang di berikan oleh apartur pemerintah darah yakni Badan Pengelolaan Lingkungan Hidup Daerah dan Satuan Polisi Pamong Praja (Satpol PP) serta Kepolisan.

b. Pengaruh penegakan hukum lingkungan terhadap perlestarian lingkungan hidup di Kabupaten Kuningan yang dilakukan secara tegas sesuai peraturan perundang-undangan harus dilakukan secara terus menerus yang menyentuh masyarakat seperti pemberdayaan masyarakat di sekitar hutan sehingga masyarakat ikut menjaga kelestarian lingkungan.

\section{Daftar Pustaka}

C.F.G. Sunaryati Hartono, Politik Hukum Menuju Satu Sistem Hukum Nasional, Bandung: Alumni, 1991.

Kartono, Penegakan Hukum Lingkungan Administratif Dalam UndangUndang Perlindungan dan Pengelolaan Lingkungan Hidup, Jurnal Dinamika Hukum, Vol.09 No. 3, Purwekerto: FH UNSOED, 2009. 
Lawrence M. Friedman, American Law: An invalueable guide to the many faces of the law, and how it affects our daily lives, New York: W.W. Norton \& Company, 1984.

Lili Rasjidi, Filsafat Hukum Apakah Hukum Itu?, Bandung: Remaja Rosdakarya, 1991.

Max Weber dalam A.A.G. Peters dan Koesriani Siswosoebroto, Hukum dan Perkembangan Sosial (Buku I), Jakarta: Sinar Harapan, 1988.

Mochtar Kusumaatmadja, Fungsi dan Perkembangan Hukum dalam Pembangunan Nasional, Bandung: Binacipta, 1986.

Nana Sudiana dan Hasmana Soewandita, Pola Konservasi Sumber Daya Air di Daerah Aliran Sungai Siak, Jurnal Alami Vol. 12 Nomor 1, 2007.

Roeslan Saleh, Penjabaran Pancasila dan UUD 1945 Dalam Perundangundangan, Jakarta: Bina Aksara, 1979.

Satjipto Rahardjo, Masalah Penegakan Hukum, Bandung: Sinar Baru, 1983.

Siti Kotijah, Implementasi Prinsip-prinsip Kehutanan dalam Rangka Konservasi Kehutanan: studi kasus di Jawa Timur, Jurnal Magister Hukum, Vol. 1 Nomor 2, Surabaya : Program Studi Magister Ilmu Hukum, Universitas Wisnuwardhana, 2010.

Soerjono Soekanto, Penegakan Hukum, Jakarta: BPHN \& Binacipta, 1983.

, Pengantar Penelitian Hukum.cet.2007, Jakarta :

UI Press, 1984.

Jakarta:Ind-Hill 1990.

Suwari Akhmaddhian, Peran Pemerintah Daerah dalam Mewujudkan Hutan Konservasi Berdasarkan Undang-undang Nomor 41 tahun 1999 tentang Kehutanan (Studi di Kabupaten Kuningan), Jurnal Dinamika Hukum, Vol.13 No. 3 September 2013, Purwekerto : FH UNSOED. 